\title{
Socio-economic Valuations of Wetland Based Occupations of Lower Gangetic Basin through Participatory Approach
}

\author{
Malabika B. Roy ${ }^{1}$, Pankaj K. Roy ${ }^{2}$, Nihar R. Samal ${ }^{3} \&$ Asis Mazumdar $^{2}$ \\ ${ }^{1}$ Gandhi Centenary B. T. College, Habra, West Bengal State University, West Bengal, India \\ ${ }^{2}$ School of Water Resources Engineering, Jadavpur University, West Bengal, India \\ ${ }^{3}$ Department of Civil Engineering, National Institute of Technology, West Bengal, India \\ Correspondence: Pankaj K. Roy, School of Water Resources Engineering, Jadavpur University, West Bengal, \\ India. E-mail: pk1roy@yahoo.co.in/malabikabiswasroy@gmail.com
}

Received: May 2, 2012 Accepted: August 20, 2012 Online Published: September 1, 2012

doi:10.5539/enrr.v2n4p30 URL: http://dx.doi.org/10.5539/enrr.v2n4p30

\begin{abstract}
Wetland is very important source of natural resources, upon which the rural economy depends. Wetlands provide many substantial benefits not only to local society, but also to the people, who live far away from wetlands. These benefits are mainly numerous services, flood control, groundwater recharging and pollution reduction. Naturally, from the point of view of economy as well as ecology, the significance of wetland and stakeholders' participation for preserving the wetland is huge. The objective of the present paper is to evaluate the economic valuation of an important floodplain wetland in the lower Gangetic basin. The focus is extended to notice the status of different mouzas with respect to their economic structure through cluster analysis and to optimize the number of working population involved in different occupations in such a way that the per capita economic valuation of each mouza is maximized. In this study, the wetland related occupations are selected and with help of income estimation method, the economic valuation of every mouza is calculated. Minitab- 15 is applied to get a complete scenario of status of the mouzas in terms of their economic structure through the cluster analysis. However, the optimization problem boils down with the help of Matlab environment. The management options are also highlighted to conserve the wetland as well as to uplift the stakeholders' livelihood. With the help of different analysis, the paper concludes that the majority of the population should go for farming followed by fishing and then other occupations.
\end{abstract}

Keywords: wetland based occupations, economic model, socio-economic evaluation, cluster analysis, optimization problem, management options

\section{Introduction}

From the past, wetlands are the most productive ecosystem in the earth, recognised globally for their vital role in sustaining a wide array of biodiversity and provide goods and services (Ramachandra, Alkananda, Rani, \& Khan, 2011). It was found in history that, through the central part of art, literature, mythology, and religion, wetlands played an important role of the life and the culture of early people. Now the importance of wetlands has changed with time. Wetlands have been described both as "the kidneys of the landscape", because of the functions they can perform in the hydrological and chemical cycles, and as "biological supermarkets" because of the extensive food webs and rich biodiversity they support (Mitsch \& Gosselink, 1993). Wetlands support millions of people, not only to the local population living in their periphery but also to the world outside the wetland. Naturally, an estimate of a monetary value for wetlands and attitudes toward wetland conservation is the major factor to be considered in policy decisions.

There are some studies available on multiple purposes, including the wetland valuations. For examples, Gren, Groth and Sylven (1995) made a rough calculations of values by transferring results, obtained in other studies to the Danube flood plains. However, Verma, Bakshi and Nair (2001) evaluated fully the wetland benefits/ resources for appropriate allocation of wetland use in case of Bhoj wetland in India. He also helped the planners and the policy makers, to develop a socially acceptable, environmentally sound and economically feasible strategy for wetland management. Whereas, Schuyt (2005) emphasized the importance of the wetland for the local population in Africa and the economic consequence for these people if the wetlands are degraded. On the 
other hand, Kosz (1995) found out the value of ecological quality of the river side wetlands of "Donau- Auen" national park. The environmental goods, which he considered, were valued by the means of willingness-to-pay (WTP) survey. Moreover, Kontogianni, Skourtos, Langford, Bateman, and Georgiou (2001) focussed a mixed methodology approach questionnaire survey of individuals and stakeholders focus groups to investigate economic values placed in wetland surrounding Kalloni Bay on the island of Lesvos, Greece. Even, Ahmed, Islam, Rahman and Halim (2007) determined the techniques for traditional management of schumannianthus dichotoma plantation and its role in the household economy in two villages in Gowainghat Thana (subdistrict) in Sylhet district, Bangladesh. Riegels, Siegfried, Cardenal, Jensen, and Bauer-Gottwein (undated) presented an economics-based approach for river basin-scale optimization that combines a detailed hydrologic model with an economic valuation tool to estimate the costs and benefits of different water allocation plans developed for the Syr Darya River Basin. Even so, Streever, Callaghan-Perry, Searles, Steven and Svoboda (1998) estimated a willingness-to-pay (WTP) value and examined attitude about the wetland conservation in New South Wales, Australia. Morton (1990), however, calculated the value of marketable fish in the mangrove habitat of Moreton Bay, Queensland, Australia, at A\$ 8389 per hactor (A\$ = Australian dollar). Stevens, Benin and Larson (1995), furthermore, published the results of a contingent valuation study that estimated the values of wetlands in the New England region of United States. Turner (2000), whereas, emphasized an integrated wetland research framework, which suggests that a combination of economic valuation, integrated modelling, stakeholders analysis, and multi-criteria evolution can provide complementary insights into sustainable and welfare-optimizing wetland management and policy. Moreover, Kangalawe and Liwenga (2005) focused on the opportunities and challenges related to integrated water resources management in Kilombero valley, Tanzania, on the dynamics and benefits of natural resource use in the wetland. Joseph (2003), furthermore, drew on the dependency paradigm to explain the development of enclave tourism and its socio-economic impacts in the Okavango Delta, Botswana. Since the tourism in the Okavango Delta can not be described as being sustainable from a socio-economic perspective, the author adopted policies and strategies that will ensure the substantial amounts of tourism revenue that are retained in the Okavango and Botswana. While, Ando and Getzner (2005) used data on patterns of wetland conservation in Austria in order to identify patterns in government decisions regarding which wetlands to protect. Moreover, using results from previous 39 studies, Woodward and Wui-Yong (2001) evaluated the relative value of different wetland services, the sources of bias in wetland valuation and the returns to scale exhibited in wetland values. Nyakaana (2008), however, evaluated the socio-economic benefits of consumptive utilization practice of wetland resources, the recreation and eco-tourism potential of the wetland, its sustainability and contribution to poverty reduction among the surrounding communities. Furthermore Pate and Loomis (1995) determined that if distance affects willingness to pay for public goods with large non-use values. In the context of lower Gangetic plain related journals, Das et al. (2002) estimated the economic value of ten wetlands in the Gangetic flood plain in Bardhaman district of West Bengal. The area of the wetlands varies from 10 ha to 275 ha with an average area of 66 ha. The estimated economic benefit from fisheries operation varies from INR 500 to INR 16, 000 per ha per year; average irrigation benefit is INR 3.543 with a maximum of INR 16,000; average benefit of using wetland for jute retting is INR 200 per ha per year with a maximum of INR 625 per ha per year. Average benefit from fisheries operation varies from INR 2,484 per household, irrigation benefit - INR 1,105 per acre and jute retting INR 483 per household per year. However, Mukherjee (2008) showed that the major economic benefits that people living in the surrounding area of wetland derive are from wetland cultivation; direct irrigation; jute retting; and fisheries. He selected a wetland in Bardhaman district of West Bengal, India and found that the most important benefit was from fisheries, followed by wetland cultivation and jute retting and the irrigation benefits were found to be low due to larger distance of the land from the wetland, and the easy access to shallow groundwater in the region. Chattopadhyay (2002) estimated the potential losses due to conversion of 1500 ha of East Calcutta Wetlands in the year of 1999-2000 as INR 338.90 million. The willingness to pay of the stakeholders to conserve the East Calcutta Wetland, the amount varies from INR 60/per household /year to INR 1200/per household/year, with an average of INR 380/per household/year.

The present study is focused on economic valuation of different wetland activities in a perennial fresh water wetland in West Bengal, India. Though, Bhattacharya, Mukherjee and Garg (2000) identified wetlands in West Bengal, it is difficult to identify the wetlands according to their uses. Based on the ecological condition and pressure from economic activities, wetlands in different areas are used for different purposes. Therefore it is difficult to identify wetlands, which are used as Multiple Use Systems (Mukherjee, 2008).

Even, Biswas (2008) stated that the groundwater in 17 blocks of the district, Nadia in West Bengal, is contaminated with Arsenic. Moreover, it is also needed to state that the whole area is densely populated. The average population density in the area around the wetland is 966.978 per square kilometer (The detail study in 
this context has given in Table 1). In this situation, the importance of the fresh water wetlands in lower Gangetic basin, especially the arsenic affected area, is huge and cannot be neglected. For this study, the selected wetland not only provides fresh water to the people of arsenic affected area, but also is situated in Nadia district. So like the ecological and socio-economic aspects, from the geographically point of view, the study area is also remarkable.

Like the other types of wetland, fresh water wetlands are complex ecological systems, whose structure provides goods or products involving some direct utilization of one or more wetland characteristics, while wetland eco-system processes provide us with ecologically related services, supporting or protecting human activities or human properties without being used directly (Wattage \& Mardle, 2005). The stock of wetland, hence, is a multifunctional resource. Since wetlands have highly significant economic value, so it is very necessary to evaluate the wetlands services upon which the people around the wetlands depend through their different livelihood activities.

\section{Materials and Methods}

\subsection{Study Area}

The district, Nadia is situated in the heart of the Bengal delta held within the arms of the Ganga namely, the Hooghly Bhagirathi. The district is bounded on the northeast and east by Bangladesh and Topic of Cancer is passed through the district. In Nadia district, excluding private tank and river, 12954 ha water bodies as delineated in Figure 1 can be effectively utilized as a resource. Since Bhomra Beel is the largest beel in this area, so here Bhomra Beel is taken into consideration as a study area for this paper.

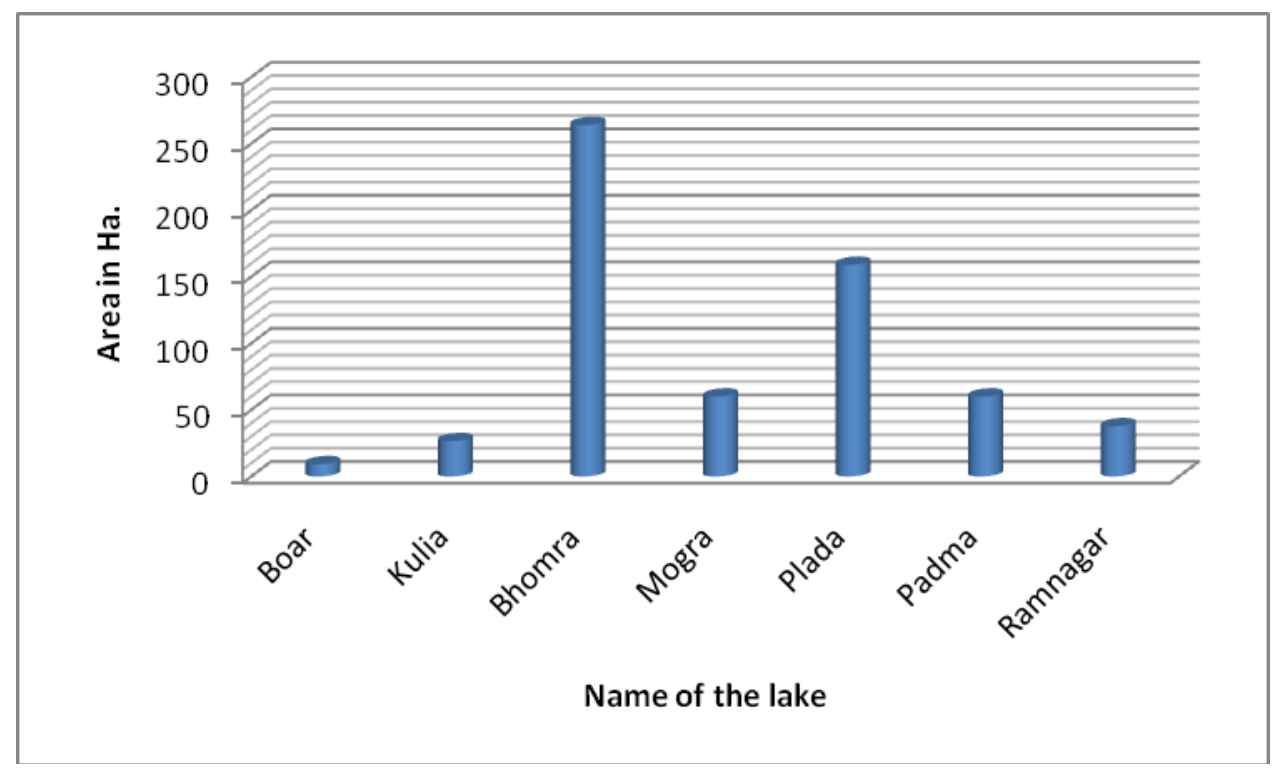

Figure 1. Some important beel of Nadia District

Apart from the similar characteristics of different wetlands, located in rural eastern India, particularly Bhomra beel is considered in the present study, keeping in view of the over pressure of the surrounding population in terms of farming and fishing. Bhomra beel is situated under Kastadanga-1 and Kastadanga-2 Gram- Panchayet, Haringhata block of Nadia District, West Bengal, India. It is an oxbow lake covering 264 hectare, which derives its origin from the river Yamuna. The Bhomra Beel is located in between $22^{0} 59^{\prime} \mathrm{N}-23^{\circ} \mathrm{N}$ and $88^{\circ} 38^{\prime} \mathrm{E}-88^{\circ} 40^{\prime}$ E. The land-use map of Bhomra beel is depicted in Figure 2. The Bhomra beel is owned by the Government of West Bengal and managed by the Bhomra Fishermen's Co-operative Society. Due to excess water withdrawal in pre-monsoon period, for agri-irrigation, the level of water is decreased. The depth varies from $2.5 \mathrm{~m}$ (during September, October) to $1.5 \mathrm{~m}$. It is fed is by a stream flowing from an adjacent upland and also gets water from the River Yamuna. The main wetland plants are algae, water hyacinth, water lily etc. The water is used for pisci-culture, domestic as well as agricultural purposes. Fishing is practiced on commercial basis with the help of modern fishing implements. The command area of this wetland is nearly 750 ha. In the past, this water body used to get polluted due to retting of raw jute, but now this problem has been done away with and mat sticks 
were prepared from one of the wetland plants and tortoise, ducks, frogs, migrated bird and other faunas are also found in this beel.

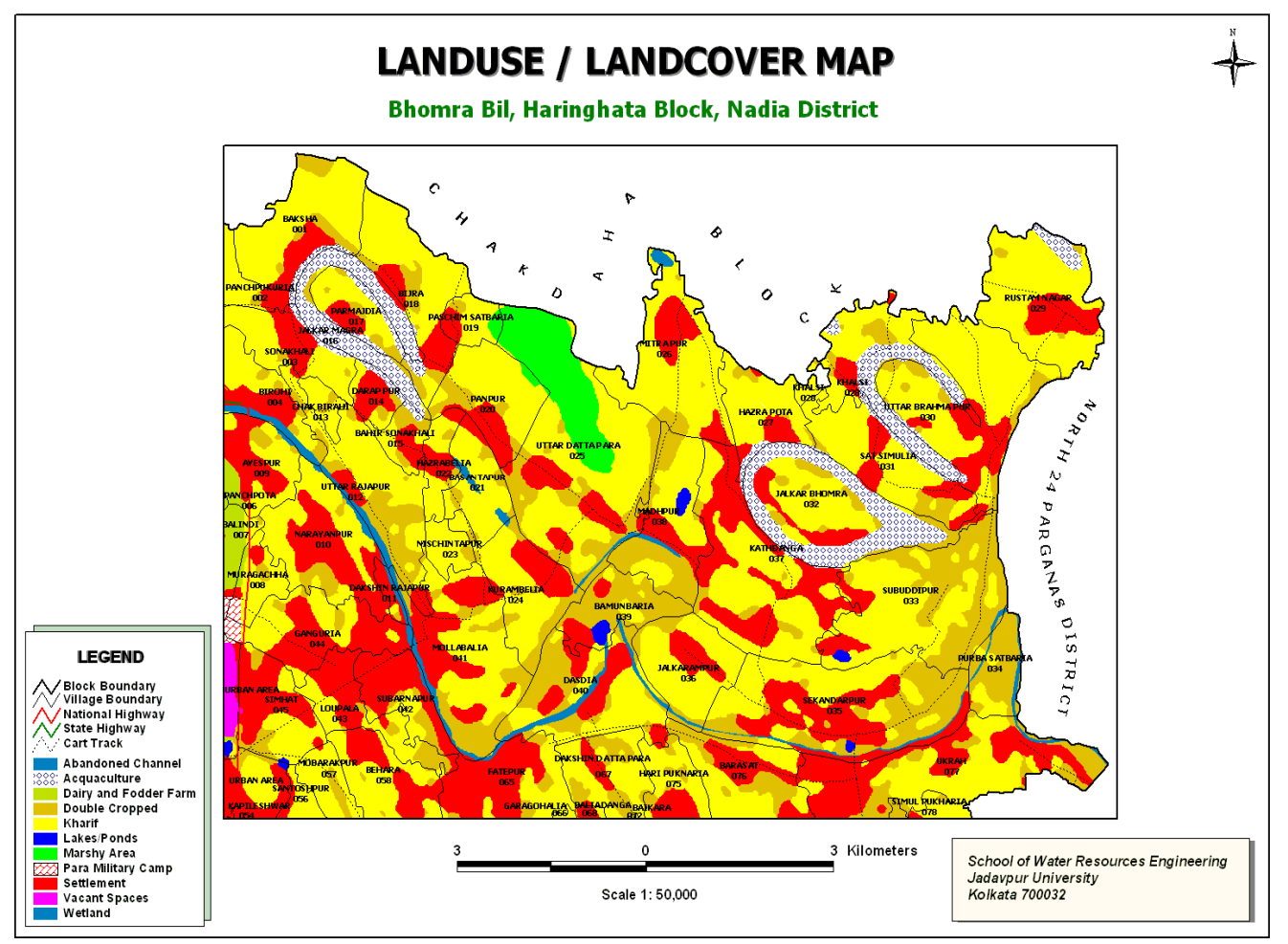

Figure 2. Land use map of Bhomra beel in West Bengal

This is the cut off portion of river meanders. The basin is relatively narrow, long, deep and have either bent or straight shapes. It derives the name from its shape, which is usually hours-shoe shaped, crescent shaped or serpentine. It receives water from the parent river through the old channel or neighbouring catchment area of Bhomra beel in West Bengal. The beel is completely cut-off from the nearby rivers and receive water mostly from the catchment area following monsoon rains or during high flood. In recent years, riverine embankments constructed to prevent floods have converted many open beels into closed ones by blocking the reverie connections.

Table 1. Demographic profile in the adjoing mouza of the Bhomra beel (Census, 2001)

\begin{tabular}{llllllllll}
\hline Block & Mouza & $\begin{array}{l}\text { Area } \\
\text { in } \\
\mathrm{km}^{2}\end{array}$ & $\begin{array}{l}\text { Total } \\
\text { Pop }\end{array}$ & $\begin{array}{l}\text { Population } \\
\text { density } \\
(\text { per } \\
\mathrm{km})\end{array}$ & sq & Population & \multicolumn{2}{l}{$\begin{array}{l}\text { Literacy } \\
(\%)\end{array}$} & rate \\
& & & & & & & \\
Haringhata & Jalkarbhomra & 3.64 & 2046 & 562.09 & $50.9 \%$ & $49 \%$ & 55.52 & 32.6 \\
Haringhata & Uttar Brambhapur & 4.16 & 4749 & 1141.6 & $52.3 \%$ & $47.7 \%$ & 73.2 & 56.7 \\
Haringhata & Satsimulia & 2.35 & 2545 & 1082.9 & $52.2 \%$ & $47.8 \%$ & 75.32 & 57.1 \\
Haringhata & Hazrapota & 1.44 & 1123 & 779.9 & $50.2 \%$ & $49.8 \%$ & 71.81 & 58.5 \\
Haringhata & Subudhipur & 4.46 & 5657 & 1268.4 & $52 \%$ & $48.01 \%$ & 86.45 & 24.02 \\
\hline
\end{tabular}

Bhomra Beel is surrounded with five mouzas. These mouzas are Jalkar bhomra, Hazrapota, Subudhipur, Uttar 
Bramhapur and Satsimulia. The demographic features of adjoining mouzas of the Bhomra beel are depicted in Table 1. The five different mouzas are densely populated compared to the Block of Haringhata and the decade at $16.32 \%$ variation in rural population is also quite significant. The population literacy rate is high of the male population as compared to female population. The data, which is presented in Table 1, is collected from census report, which was published in 2001.

\subsection{Data Acquisition}

The present study is mainly based on the primary data and information is collected through a household survey from the five mouzas viz. Jalkar bhomra, Hazrapota, Subudhipur, Uttar Bramhapur and Satsimulia in and around the wetland system, during the time period 2002-2007. A stratified sample of households was chosen, by compiling a census of village households with participatory rural appraisal techniques (Adhikari, Falco \& Lovett, 2003). The size of the collected sample of the total interviewed families is 250 . This sample is depicted in the following Figure 3. Here size of the sample is 1466. The size of the collected sample is the largest at Subudhipur. Out of the total sample, 814 are the number of male and 653 are the number of female. In the sample, the maximum number of males (206) has found at the mouza, Sububhipur, followed by Uttarbramhapur (163), Jalkarbhomra (160), Hazrapota (155), and among the five mouzas, sample revealed that the minimum number of males (130) has found in Satsimulia. On the other hand, the maximum number of females (142) has found at the mouza, Uttarbramhapur, followed by Hazrapota (139) and from the sample, it can be observed that the number of females in the mouzas, Subdhipur, Jalkarbhomra, and Satsimulia are 127, 125 and 120 respectively. Now, Figure 3 is considered below.

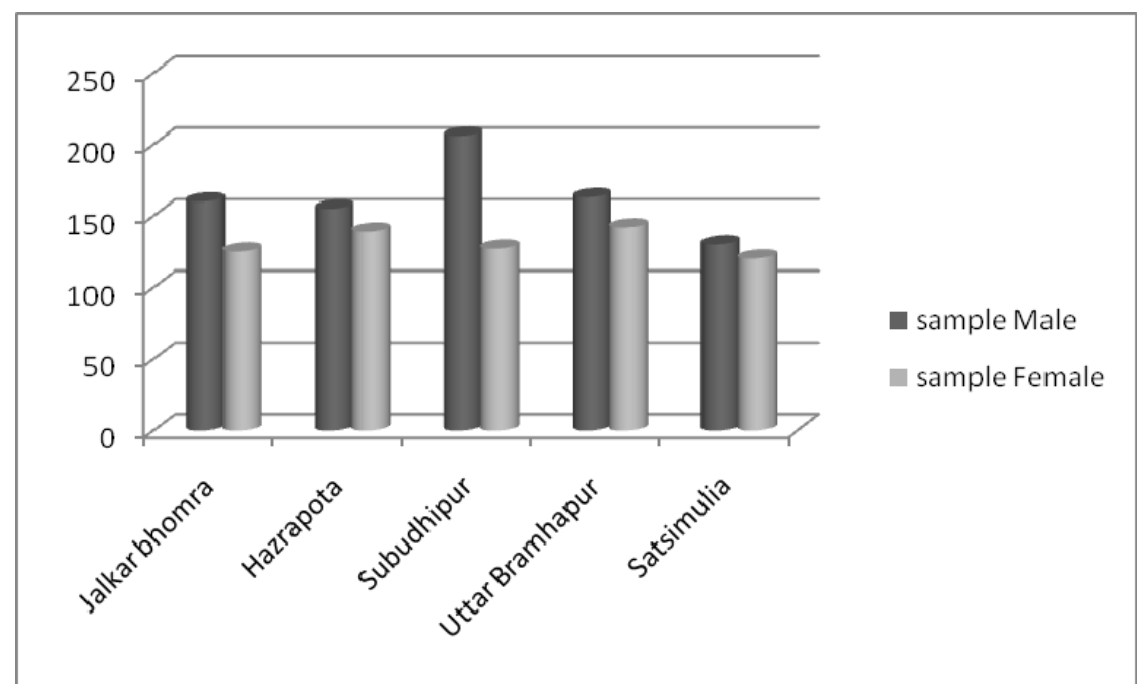

Figure 3. Sample of the number of male and female in the adjoining the mouzas of Bhomra beel

Now let us consider the literature status of the stakeholders of mouzas in Bhomra beel. The actual sample size is 1467 and the number of illiterate people is about $197(13.4 \%)$. Among the illiterate population, $108(61.63 \%)$ is the number of females and $89(38.36 \%)$ is the number of males. Among the literate population, $517(46.49 \%)$ is the number of those stakeholders, who have studied up to primary standard, of them 300 are males $(58.02 \%)$, while $217(41.97 \%$ ) are females. Out of 490 , who studied up to secondary standard, 264 are the males and 226 are the females; out of 195, who have studied up to higher secondary standard, 123 are the males and 72 are the females. The remaining 38 are graduates, of which 22 are male and 16 are female. Females are illiterate more than the males, where as the males' literacy rate is higher than the literacy rate of the females for each and every standard of education. The illiteracy rate is the highest in Satsimulia mouza. Subudhipur is the highest in literate population compared to other sample mouzas. The following Figure 4 shows the education structure of the respondents' family members in the mouzas of Bhomra beel. 


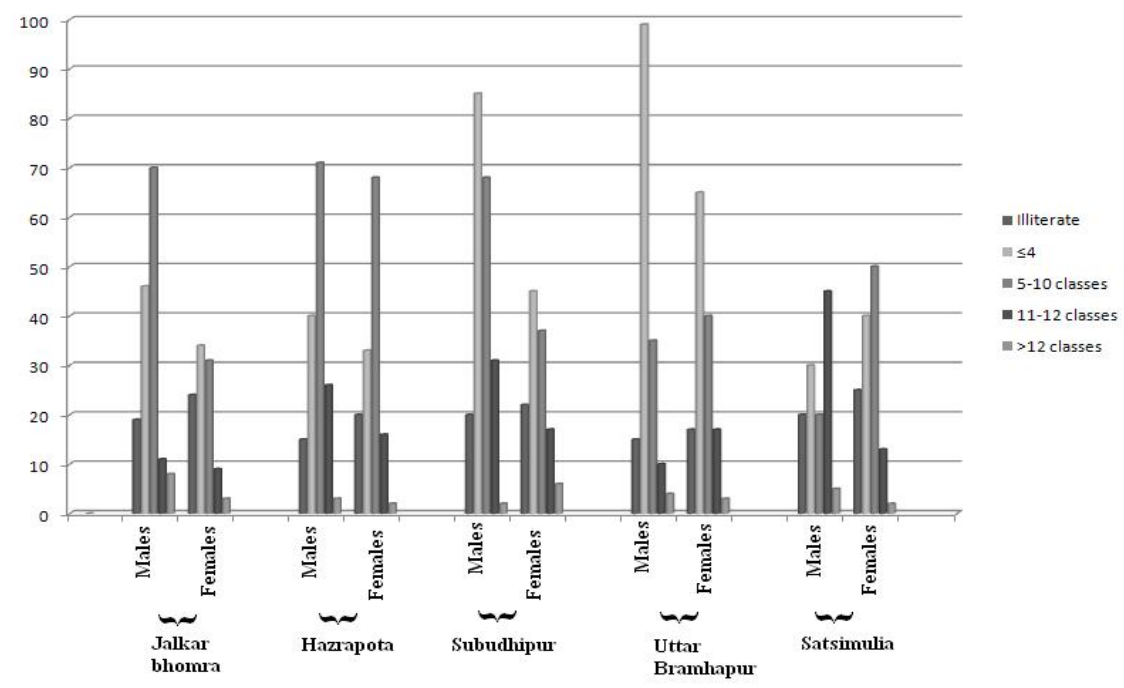

Figure 4. The education structure of the stakeholders of mouzas in Bhomra beel

Now let us consider the occupational structure of the stakeholders of the villages, which are situated, in five different mouzas of Bhomra beel. This occupational status of the respondents' families is given descriptively in the Figure 5 and 6 . The collected sample shows that out of the total work force of 744 in various sector, 131 $(17.6 \%)$ are the numbers of cultivators, of whom 131 are males and none are female; $100(13.44 \%)$ belong to agricultural landless labourers, of whom 57 are males and 43 are females; 90 (12.09\%) belong to rural cottage industry, of whom 16 are males and 74 are females; 233 (31.31\%) belong to animal husbandry, of whom 20 are males and 213 are females; 74 (9.94\%) belong to businessmen, of whom 68 are males and 6 are females; 96 (12.90\%) belong to service holders, of whom 43 are males and 53 are females; 23 (3.62\%) belong to fishermen, who are all males; and, remaining $70(9.40 \%)$ belong to the others occupations, of whom 51 are males and 19 are the numbers of females. It is clearly noticed that the number of people engaged in animal husbandry is the highest $(17.64 \%)$ followed by other occupational structures in the sample villages. The whole occupational structure is shown in the following Figures 5 and 6.

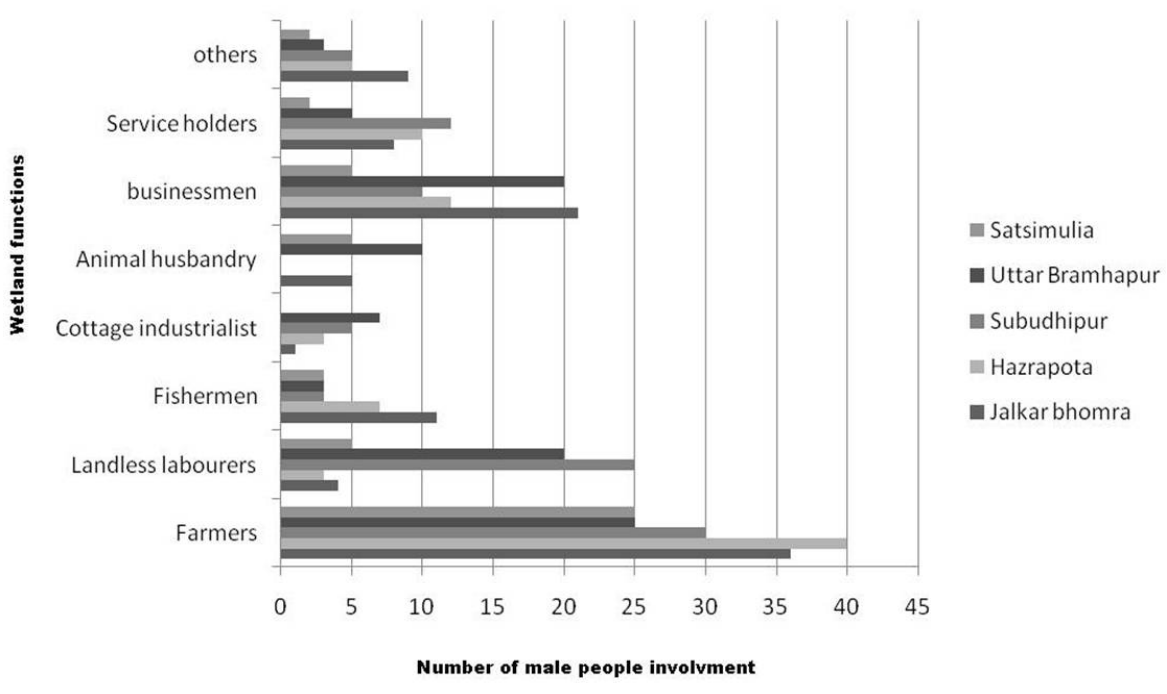

Figure 5. Occupation strcuture of males in Bhomra beel 


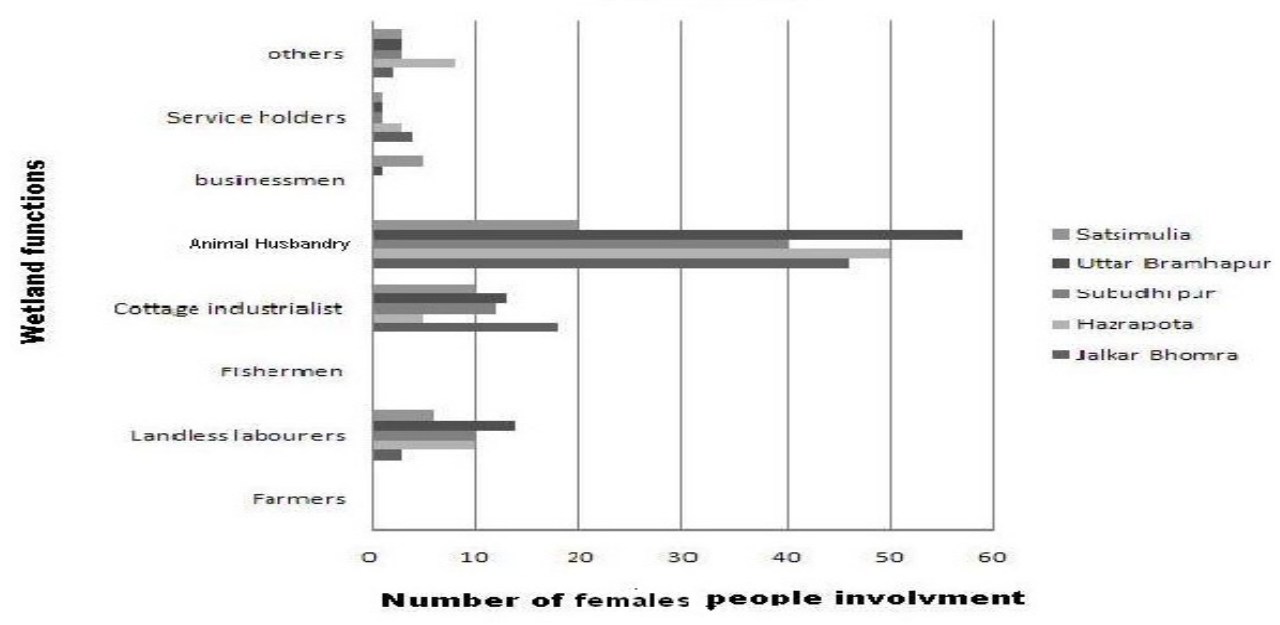

Figure 6. Occupation strcuture of females in Bhomra beel

Now let us consider the Figure 6, which represents the occupational status for female.

\section{Objectives and Methodology}

Verma et al. (2001) proposed an ecosystem model which gives the economic valuation of Bhoj wetland. He calculated the valuation of different uses or impacts of Bhoj wetland by using different valuation techniques e.g. he calculated the economic valuation of drinking water by the supply cost, fish production by market price, and recreation by CVM method. Moreover, he applied the income estimation method to calculate the economic valuation of various impacts such as boating, washing of cloths, and other different activities. Here, the income estimation technique is considered to evaluate the economic valuation of different occupations of Bhomra beel.

Bhomra Beel is adjoined by the five mouzas. The economy of these mouzas hinges on wetland and its water bodies through different wetland activities. Moreover, because of the involvement of stakeholders in various occupations is not alike and the population size of mouzas differs from each other, the economy structure of these mouzas is not identical. In this situation, it is necessary to make the cluster of different mouzas according to their economy structure. Here the cluster analysis has done to get view of similarity of mouzas with respect to their economy structure. Our next objective is to optimize the number of working population involved in different occupations in such a way that the per capita economic valuation of each mouza of the Bhomra beel is maximized.

The softwares, Microsoft Excel- 2008 and Minitab-15, under the operating system Macintosh 10.5 and Windows $\mathrm{Xp}$ (service pack 3) respectively, give clear diagrammatic representation of the data while Minitab-15 offers a relatively quick, and flexible result on cluster analysis with dendogram and in case of solving the optimization problem, Matlab environment under the operating system Windows Xp (service pack 3) gives mathematical result in details.

\section{Result and Discussion}

In the present study, the socio-economic status of the people, who live in and around the wetland, is well reflected considering the multi-attributes. The increasing recognition of the existence of environmental and social values in the recent past has led to the need to shift to a multi-attribute development system that recognizes those values as well as the traditional economic values (Wattage \& Mardle, 2005). In the context of Bhomra beel, the wetland valuation is very important because a huge number of population is depended their livelihood, directly through their different occupations, e.g. people use wetland soils and water for agriculture and irrigation purpose, they catch wetland fish to eat, they cut wetland trees for timber and fuel wood (Barbier, Acreman, \& Knowler, 1997) and this wetland is also used for different cottage industries and animal husbandry purpose, and side by side the environmental significance is deep and this significance cannot be ignored. Now To evaluate the wetland valuation, the selected occupations, such as farming, landless labourers, fishing, cottage industry, and animal husbandry are to be considered, because the remaining occupations, like business, services, and others are not directly related to the water bodies in the wetland. Moreover, Bhomra beel is not a tourist 
place, so no recreation value is needed to consider. Now, in the following Table 2, the average annual income structure of the selected occupation is considered.

Table 2. Annual (average) income structure of the stakeholders of Bhomra Beel

\begin{tabular}{lc}
\hline Occupations & Income (INR) \\
\hline Landless labourer & 475 \\
Animal husbandry & 950 \\
Cottage industry & 875 \\
Fishing & 1200 \\
Farming & 2450 \\
\hline
\end{tabular}

In the above Table 2, it can be observed that farming and fishing are those two occupations, from which the stakeholders of the Bhomra Beel can earn maximum, where as the income of landless labourers is the lowest. Since the number of stakeholders having different occupations varies from one mouza to another, it is better to calculate the economic valuation separately for each mouza by the income estimation technique. Here we have five mouzas, viz., Jalkar bhomra, Hazrapota, Subudhipur, Uttar Bramhapur, and Satsimulia. So let us consider, in the following Table 3, the economic valuation, which is calculated, for the mouza, Jalkar bhomra in the economic year, 2008-2009.

Table 3. Economic valuation for the mouza, Jalkar bhomra

\begin{tabular}{lc}
\hline Occupations & Economic valuation (INR/year; 2008-09) \\
\hline Landless labourer & 3325 \\
Animal husbandry & 48450 \\
Cottage industry & 16625 \\
Fishing & 13200 \\
Farming & 88200 \\
\hline
\end{tabular}

In above Table 3, economy in Jalkar bhomra is involved in farming and animal husbandry, while sample is shown that the economic value for fishing, cottage industry and landless labourer is Rs 13200, 16625 and 3325 respectively. Now the second mouza, Hazrapota is considered to calculate the economic evaluation in the following Table 4.

Table 4. Economic valuation for the mouza, Hazrapota

\begin{tabular}{lc}
\hline Occupations & Economic valuation (INR/year; 2008-09) \\
\hline Landless labourer & 6175 \\
Animal husbandry & 47500 \\
Cottage industry & 7000 \\
Fishing & 8400 \\
Farming & 98000 \\
\hline
\end{tabular}

In Table 4, the sample shows that although, in Hazrapota, maximum stakeholders involved in animal husbandry occupation, but the economic value is hiked up from the occupation, farming. Now, in the following Table 5, let us consider the third mouza, Subudhipur to calculate the economic valuation for the year 2008-09. 
Table 5. Economic valuation for the mouza, Subudhipur

\begin{tabular}{lc}
\hline Occupations & Economic valuation (INR/year; 2008-09) \\
\hline Landless labourer & 16625 \\
Animal husbandry & 38000 \\
Cottage industry & 14875 \\
Fishing & 3600 \\
Farming & 73500 \\
\hline
\end{tabular}

In Table 5, the sample shows that, in Subudhipur, a large number of stakeholders are landless labourer, while economy in Subudhipur depends in farming. In Table 6, the economic valuation for Uttar Bramhapur is calculated in details.

Table 6. Economic valuation for the mouza, Uttar Bramhapur

\begin{tabular}{lc}
\hline Occupations & Economic valuation (INR/year; 2008-09) \\
\hline Landless labourer & 16150 \\
Animal husbandry & 63650 \\
Cottage industry & 17500 \\
Fishing & 3600 \\
Farming & 61250 \\
\hline
\end{tabular}

The above Table 6 shows that in Uttar Bramhapur the economy mainly depends in animal husbandry, farming, cottage industry and landless labourer respectively in a row. Since in sample only 3 stakeholders, who engaged in fishing, are found, so small economic contribution from fishing sector was found. Now, in case of Satsimulia, the economic valuation is shown in the following Table 7.

Table 7. Economic valuation for the mouza, Satsimulia

\begin{tabular}{lc}
\hline Occupations & Economic valuation (INR/year; 2008-09) \\
\hline Landless labourer & 5225 \\
Animal husbandry & 2375 \\
Cottage industry & 8750 \\
Fishing & 3600 \\
Farming & 61250 \\
\hline
\end{tabular}

For the mouza, Satsimulia, sample shows through the Table 7 that the economic mainly depends on farming, while the economic value of landless laborer, animal husbandry, cottage industry and fishing are found as rupees $5225,23750,8750$, and 3600 respectively.

From the above Tables 3, 4, 5, 6, and 7, the economic valuation for the five mouzas in Bhomra beel are described in details. If a comparative study is concerned then it can be noticed from these tables that the economic valuation for farming is hiked up in Hazrapota, the economic valuation for fishing is maximum in Jalkar bhomra, the economic valuation for cottage industry and animal husbandry is maximum in Uttar Bramhapur, while the economic valuation for landless labourer is maximum in Subudhipur.

Bhomra beel is situated in the rural area of eastern India. The stakeholders, around this wetland, are not educated enough and their life style as well as their occupations depend on the stock of wetland in a direct and indirect way. Moreover, it is also observed that there are some occupations, in which the male populations are involved more than female populations and on other hand there are also some wetland functions, in which female populations are more dependent than the male populations. For this reason, the economic valuations are varied 
from each situation. But in order to get a complete idea on economic valuations with respect to the different mouzas, the cluster analysis, here, may be considered. A complete scenario of mouzas in Bhomra Beel that is the different homogeneous classes of mouzas, in terms of economic valuation is discussed in this present investigation. Cluster analysis is used to link variables (mouzas) in the configuration of a tree with different branches, (economic valuation of the wetland) that have linkages closer to each other, which indicate a stronger relationship among variables, as the clustering means grouping of the items or objectives according to their level of similarities or dissimilarities. Cluster analysis is a very useful technique in every field for data analysis. The purpose of cluster analysis is to find the homogeneous groups, and then the objects in each group have similar (or dissimilar) properties. The inputs to the clusters analysis are similarities or dissimilarities (Das \& Chattopadhyay, 2004). Cluster analysis is a data reduction method that is used to classify entities with similar properties. The method divides a large number of objects into a smaller number of homogeneous groups on the basis of their correlation structure (Hartigan, 1975). The dendrogram, which generated from tree clustering, provides a useful graphical tool for determining the number of clusters. Moreover, the dendrogram, describes underlying processes that lead to spatial variation. In the following Table 8 , the whole calculation related to the cluster analysis is done in details.

Table 8. Cluster analysis of the mouzas of Bhomra Beel

\begin{tabular}{ccccc}
\hline Steps & Similarity level & Distance level & Clusters joined & Number of observation in new cluster \\
\hline 1 & 99.5374 & 0.009251 & $-1,-2$ & 2 \\
2 & 99.4343 & 0.011314 & $1,-5$ & 3 \\
3 & 99.2205 & 0.015591 & $2,-3$ & 4 \\
4 & 93.8020 & 0.123959 & $3,-4$ & 5 \\
\hline
\end{tabular}

In the Table 8 , the required cluster analysis is made in details. In the above Table 8 , the 4th column is representing the joining of clusters with each other. Here the number before a negative sign stands for an observation while the number without negative sign represents a cluster or homogeneous group. For example, in the 1st row of the same column, the value is $-1,-2$, which represents that the 1 st cluster is formed with 1 st and 2nd observation at the level of distance 0.009251 , where as in the 2 nd row of the 4 th column the value, $1,-5$ represents that 5 th observation is more similar to the 1 st cluster than other observations (the level of distance is $0.011314)$. The level of similarities is also show in the Table 8 . The whole scenario is given in the following Figure 7.

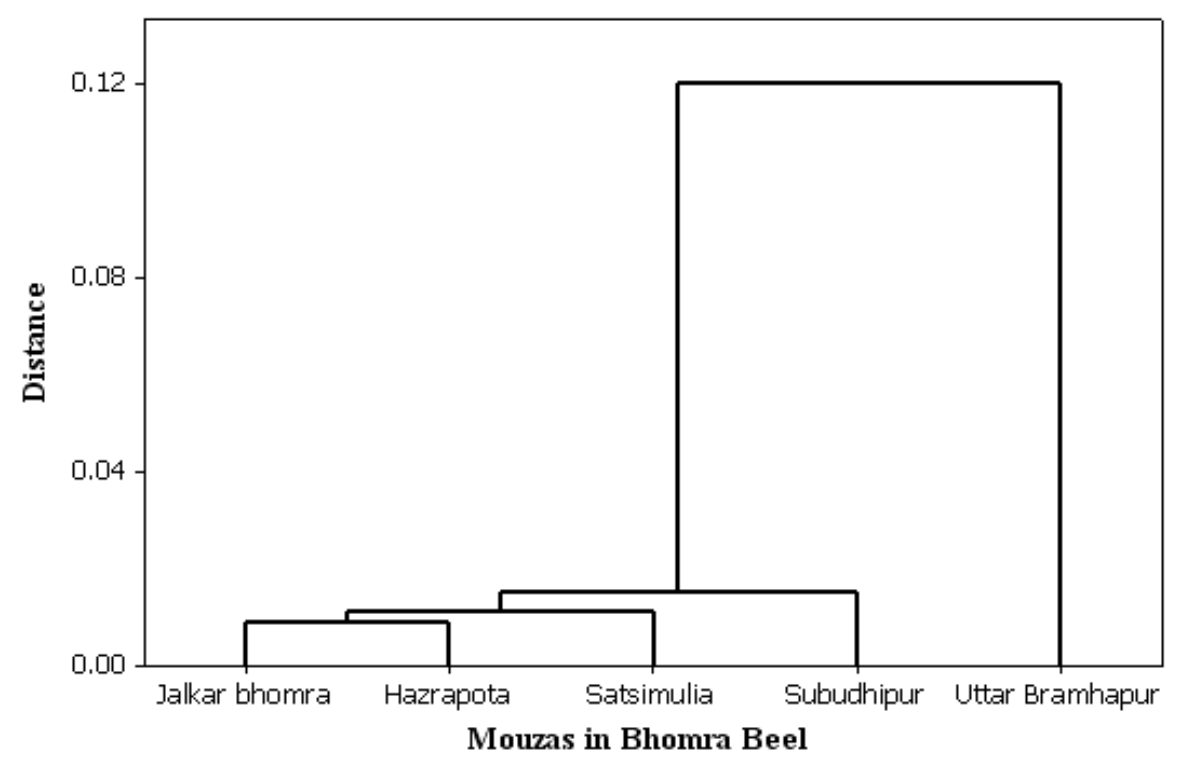

Figure 7. Cluster analysis of Mouzas with respect to economic valuations in Bhomra Beel 
Our next objective is to optimize the number of working population involved in different occupations in such a way that the per capita economic valuation of each mouza is maximized. In this connection, it is noted that this is an optimization problem. Here to materialize this objective, demographic profile in the adjoining mouzas of bhomra beel (5 mouzas), the occupational status of people of mouzas in the bhomra beel, economic valuations of the different mouzas are given in details.

First of all the total number of working population in each mouza is found and subsequently the percentage of working population $(\% \mathrm{P})$ in each mouza is found from the exist data (total population and total working population). Now the Figure 8 , which is plotted between total economic valuation and \% of working population to find the maximum $\%$ of working population, is considered in below.

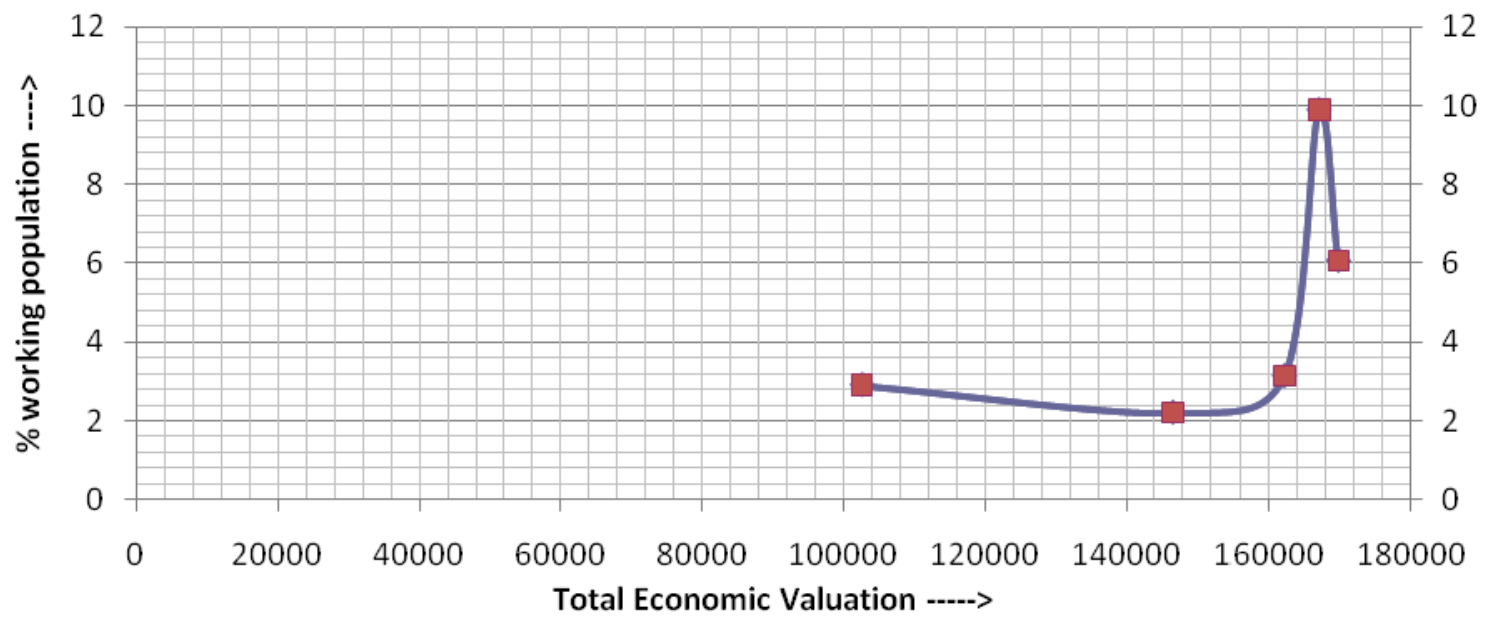

Figure 8 . Plotting of total economic valuation and \% of working population

To solve this problem, one can consider the following objective function.

$$
\mathrm{F}(\mathrm{x})=\mathrm{Z}=\mathrm{P}[\mathrm{a} \mathrm{R}+\mathrm{b} \mathrm{L}+\mathrm{c} \mathrm{F}+\mathrm{d} \mathrm{C}+\mathrm{e} \mathrm{A}]
$$

Where, $\mathrm{Z}$ is the total economic valuation which has to be maximized, $\mathrm{P}$ is maximum working population for a particular valuation, $a, b, c, d$, and e are the percentage of population, who are working in each occupation for $\max \mathrm{Z}, \mathrm{R}$ is the average per capita income of farmers of all five mouzas, $\mathrm{L}$ is the average per capita income of landless labourers of all five mouzas, $\mathrm{F}$ is the average per capita income of fishermen of all five mouzas, $\mathrm{C}$ is the average per capita income of cottage industrialists of all the mouzas, and A is the average per capita income of people working in animal husbandry of all mouzas in Bhomra beel.

Here, it is needed to mention that, for the sake of calculation procedure, the name of mouzas is abbreviated as following Table 9.

Table 9. Abbreviation of name of mouzas

\begin{tabular}{lc}
\hline Name of mouza of Bhomra beel & Abbreviated name \\
\hline Jalkarbhomra & 1 \\
Uttar Brambhapur & 2 \\
Satsimulia & 3 \\
Hazrapota & 4 \\
Subudhipur & 5 \\
\hline
\end{tabular}

In this case, it should be considered the design population $=$ average population density $*$ maximum area $=4313$. Now if one can observe the Figure 8 closely, then it can be found easily that the maximum value of the percentage of population cannot be found uniformly, as the given data is not in consistent form. For this reason, 
here, two cases are needed to consider. The case 1 is the maximum value of the percentage of population from mouzas $1,2,3,5$ and case 2 is the maximum value of the percentage of population of mouza 4 . The maximum value of $\mathrm{P}$ is found forming equation from the given data by curve fitting and then differentiating it. Here with help of Matlab software, it is found in the first case that the value of percentage of $\mathrm{P}=4.9652 \%$ and the maximum number of working population in a given occupation $=4.9652 * 4313 / 100=215$ and for the second case, the value of percentage of $\mathrm{P}=10.5 \%$ and the maximum no of working population in a given occupation $=$ $10.5 * 4313 / 100=453$. Now, with help of the Matlab environment, we have the value of a, b, c, $\mathrm{d}$ and e as follows.

Table 10. Estimated value of the percentage of population

\begin{tabular}{cccccc}
\hline The percentage of population & $\mathrm{a}$ & $\mathrm{b}$ & $\mathrm{c}$ & $\mathrm{d}$ & $\mathrm{e}$ \\
\hline Estimated values & 0.6 & 0.05 & 0.25 & 0.05 & 0.05 \\
\hline
\end{tabular}

From the result of above Table 10, it can be stated that $60 \%$ of the population should go for farming, $5 \%$ of the population should have to become labourers because of their utmost poverty being landless, $25 \%$ of the population should opt for fishing, $5 \%$ of the population should become cottage industrialists, and $5 \%$ of the population should go for animal husbandry i.e., in other words, the above results depicts that majority of the population should go for farming followed by fishing and the rest of the population should go for other occupations with equal proportion.

\section{Conclusion}

Wetlands are among the most important and yet most threatened eco-systems in India. In the present study, Bhomra beel is perennial wetland in this flood-plain area and it may be concluded that fishing is a major occupation throughout the year in comparison to the agro-irrigation, where the large amount of water withdrawal is necessary.

Wetlands are a precious part of our cultural and natural heritage, providing an extremely important resource for many human interests and activities, as well as habitats that support a rich diversity of faunal and floral life. After observing the qualitative analysis in details, it can be concluded that a distingushiable pattern is emerging in the educational structure of the male and female. Moreover, it is also observed that the male populations are dependent particularly on fishing and faming where as the female community is engaged in mainly animal husbandry and cottage industry.

The livelihood of the community living in and around the wetland is benefited and receives a lot of services e.g farmers and landless labours use the water bodies for irrigation purpose. Similarly fishermen, cottage industrialists and the people, who are engaged in animal husbandry, use water bodies directly. Therefore, the importance of the wetland in stakeholders' livelihood is enormous and side by side, because of preservation of fresh water bodies, evaluating the economic valuation, it is also necessary for the wetland.

In this paper, the economic valuation is calculated with help of a sample of size 1466 by using the income estimation method. After a detailed quantitative study, it has been found that although fishing is a major occupation for the stakeholders of Bhomra Beel, the economic structure of five mouzas is mainly based on farming and animal husbandry. Moreover, the interesting subject in this context is that though animal husbandry is not a major profession but it plays a major role in economy of that area, because animal husbandry is the job which involves less time and labours. So almost every stakeholder's for all mouzas interest is to get involved in this occupation for higher return.

In this study, the mouzas are divided according to their economic structure into some homogeneous groups or clusters through the cluster analysis. With the help of the dendogram, it can be concluded that the economic standard of Jalkar Bhomra and Hazrapota is similar while the dissimilarity between Uttar Bramhapur and other mouzas is maximum with respect to the economic status.

Through this paper, the optimum number of working population, involved in different occupations is calculated through a simple economic model and the per capita economic valuation of each mouza is maximized. The total calculation procedure indicates that $85 \%$ of the total population in these mouzas should choose two major occupations which are farming and fishing. Thus in an attempt to find new solutions to the various problems in the wetland management, resulting from top-down approaches to resource conservation and sustainability, community-based co-management recognizes that local communities should have direct control over the 
management, utilization and benefits of local resources (in this context land, water and fishery resources) in order to value and use them in a sustainable manner.

\section{Management Options to Conserve the Bhomra Beel}

From the aspects of socio-economic, ecology and geography, Bhomra beel plays an important role not only the Nadia district, but also in West Bengal. It is one of large, fresh water lake in rural India. There is no doubt that preservation of Bhomra beel is essential. The following points are in favour of the adaptive reuse of Bhomra beel:

The area around Bhomra beel has dense population. Naturally, there is an extreme pressure on environment because stakeholders cut the trees and prepare the land for living and agricultural purpose. Therefore, it is very essential to find out the proper sustainability to make a balance between environment and population.

Fishing occupation should be more accepted by the local people than agriculture because a huge amount of water is needed to withdraw from the beel for cultivation. For this reason, the level of water is decreased and consequence of which, the life of flora and fauna in the water is getting hampered.

The Bhomra Fishermen's Co-operative Society manages the fishery occupation of the stakeholders of Bhomra beel. After observing their management system closely, it is necessary to remark that this co-operative society should more concentrate on the fishing activities of the fishermen, because the fishing should be in such way that the maximum profit can be gained as well as the population of fishes is maintained in proper level.

Like the Bhomra Fishermen's Co-operative Society, the local government should think to build co-operative society of other occupations, because large amount of money is circulated through farming, cottage industry, animal husbandry and some other water based occupations, such as Hogla Cultivation, Mat cultivation, Floriculture, Goatery, Shola Cultivation, Makhana and Paniphal cultivation, Cultivation of lotus and aquarium plants, and Cultivation of supplementary vegetables and medicinal herbs. Only a co- operative society can organize all businesses in proper way. Not only that many common people, who engage in these professions, can be more benefitted. Moreover, large number stakeholders, who are in out of labour force, can get job.

Bhomra beel is used for domestic purpose. For example, stakeholders bath in the water of the lake, they use the water cooking, drinking and washing clothes, bathing of domestic animals is also one purpose, for which the lake is used. Naturally, a regular monitoring and analysing of water quality and hence developing a database for risk evaluation is essential for the water of Bhomra beel.

There are many species and plants, which have permanent or semi permanent livelihood in and around Bhomra beel. Nowadays, increasing of human population and their different activities are hampering the livelihood of these species and plants. As a result, these species and plants may be in included in endangered list. Therefore, the local government should take necessary steps to protect their life for the sake of biodiversity.

Plastics are the major problem for the water of the water body. Therefore, ban on use of plastics, prevention of non-point source pollution, and implementation of integrated Solid Waste Management (SWM) as per the guidelines of the national SWM committee are needed to protect the entire environment.

Bhomra beel is fresh water wetland beside the highly arsenic affected area. Therefore, the proper utilizing the water resource will be an important source of drinking water for people, who live in the arsenic affected area.

Finally, the participation of each and every stakeholder is needed more, not only preserve or conserve the Bhomra beel, but also emerging his or her life style and livelihood and this whole process can be successful through proper training of stakeholders of Bhomra beel.

\section{References}

Adhikari, B., Falco, D. S., \& Lovett, J. C. (2003). Household characteristics and forest dependency: evidence from common property forest management in Nepal. J. Ecological Economics, 48, 245-457. http://dx.doi.org/10.1016/j.ecolecon.2003.08.008

Ahmed, R., Islam, A. N. M. F., Rahman, M., \& Halim, M. A. (2007). Management and economic value of Schumannianthus dichotoma in rural homesteads in the Sylhet region of Bangladesh. International journal of Biodiversity Science and Management, 3, 252-258.

Ando, A. W., \& Getzner, M. (2005). The roles of ownership, ecology, and economics in public wetland-conservation decisions. Ecological Eeconomics, $287-303$. http://dx.doi.org/10.1016/j.ecolecon.2005.07.013

Barbier, E. B., Acreman, M., \& Knowler, D. (1997). Economic valuation of wetlands. A guide for policy makers 
and planners. Ramsar Convention Bureau Gland, Switzerland.

Bhattacharyya, S., Mukherjee, K., \& Garg, J. K. (2000). Wetlands of West Bengal, Institute of Wetland Management and Ecological Design. Calcutta and Space Application Centre, Ahmedabad.

Biswas, M. (2008). Participatory management of ecosystem services: A study of wetland in West Bengal. Ph.D thesis. School of Water Resource Engineering, Jadavpur University, Kolkata, India.

Census. (1991-2001). Government of India.

Chattopadhyay, K. (2002). Environmental Conservation and Valuation of East Calcutta Wetlands, Final Re- port, Funded by Environmental Economics Research Committee, World Bank Aided India: Environmental Management Capacity Building Program.

Das, K., \& Chattopadhyay, A. K. (2004). Statist. Med, 23, 2895-2910. http://dx.doi.org/10.1002/sim.1862

Das, T. K., Moitra, B., Raichaudhuri, A., Jash, T., Ghosh, S., \& Mukherjee, A. (2002). Degradation of Water Bodies and Wetlands in West Bengal: Interaction with Economic Development, Final Report, Funded by Environmental Economics Research Committee, World Bank Aided India: Environmental Management Capacity Building Program.

Gopal, B., \& Sah, M. (1995). Inventory and Classification of Wetlands in India. Plant Ecology, 118(1- 2), 39-48.

Gren, Ing-M., Groth, Klaus-H., \& Sylven, M. (1995). Economic valuation of Danube Floodplains. Journal of Environmental Management, 4, 333-345.

Hartigan, J.A. (1975). Clustering algorithms. New York. John Wiley \& Sons.

Joseph, E. M. (2003). Enclave tourism and its socio-economic impacts in the Okavango Delta, Botswana. Tourism Management, 26, 157-172.

Kangalawe, R. Y. M., \& Liwenga, E. T. (2005). Livelihood in the wetlands of Kilombero Valley in Tanzania: Opportunities and challenges to integrated water resources management. Physics and Chemistry of the Earth, 30, 968-975. http://dx.doi.org/10.1016/j.pce.2005.08.044

Kontogianni, A., Skourtos, M. S., Langford, I. H., Bateman, I. J., \& Georgiou, S. (2000). Integrating stakeholder analysis in non-market valuation of environmental assets. Ecological Economics, 37, 123-138. http://dx.doi.org/10.1016/S0921-8009(00)00270-6

Kosz, M. (1995). Valuing riverside wetlands: the case of "Donau- Auen" national park. Ecological Economics, 16, 109-127. http://dx.doi.org/10.1016/0921-8009(95)00058-5

Mitsch, W. J., \& Gosselink, J. G. (1993). Wetlands. Van Nostrand Reinhold (2nd ed.). New York.

Morton, R. M. (1990). Community structure, density and standing crop of fishes in a subtropical Australian mangrove area. Marine Biology, 105, 385-394. http://dx.doi.org/10.1007/BF01316309

Mukherjee, S. (2008). Economic Valuation of a Wetland in West Bengal, India. International Water Management Institute (IWMI)-TATA Water Policy Research Program.

Nyakaana, J. B. (2008). Sustainable wetland resource utilization of Sango Bay through Eco-Tourism development. African Journal of Environmental Science and Technology, 2(10), 326-335.

Pate, J., \& Loomis, J. (1995). The effect of distance on willingness to pay values: a case study of wetlands and $\begin{array}{lllll}\text { salmon in } \quad \text { California. Ecological } & \text { Economics, } & 20, & 199-207 .\end{array}$ http://dx.doi.org/10.1016/S0921-8009(96)00080-8

Schuyt, K. D. (2005). Economic consequences of wetland degradation for local population in Africa. Ecological Economics, 53, 177-190. http://dx.doi.org/10.1016/j.ecolecon.2004.08.003

Ramachandra, T. V., Alakananda, N., Rani, A., \& Khan, M. A. (2011). Ecological and socio-economic assessment of varthur wetland, Bengaluru (India). Journal of Environmental Science \& Technology, 53(1), 101-108.

Riegels, N. D., Siegfried, T., Cardenal, S. J. P., Jensen, R. A., \& Bauer-Gottwein, P. (Undated). An Economics-Driven Approach for Optimizing Water Use in Transboundary River Basins.

Stevens, T. H., Benin, S., \& Larson, J. S. (1995). Public attitudes and economic values for wetland preservation in New England. Wetlands, 15, 226-231. http://dx.doi.org/10.1007/BF03160702

Streever, W. J., Callaghan- Perry, M., Searles, A., Steven, T., \& Svoboda, P. (1998). Public attitudes and values for wetland conservation in New South Wales, Australia. Journal of Environmental Management, 5, 1-14. 
http://dx.doi.org/10.1006/jema.1998.0224

Turner, R. K. (2000). Valuation of Wetlands in a Landscape and Institutional Perspective. Ecological Economics, 35, 1-6. http://dx.doi.org/10.1016/S0921-8009(00)00163-4

Verma, M., Bakshi, N., \& Nair, R. P. K. (2001). Economic valuation of Bhoj Wetland for sustainable use. Project undertaken for the World Bank Aided India: Environmental Management Capacity Building Technical Assistance Project implemented by the Ministry of Environment and Forest and Coordinated by EERC Implementation Cell at IGIDR, Mumbai, India, 13-20.

Wattage, P., \& Mardle, S. (2005). Stakeholder preferences towards conservation versus development for a wetland in Sri Lanka. Journal of Environmental Management, 77, $122-132$. http://dx.doi.org/10.1016/j.jenvman.2005.03.006

Woodward, R. T., \& Wui-Yong, S. (2000). The economic value of wetland services: a meta-analysis. Ecological Economics, 37, 257-270. http://dx.doi.org/10.1016/S0921-8009(00)00276-7 